\title{
Helminths of rabbits (Lagomorpha, Leporidae) deposited in the Helminthological Collection of the Oswaldo Cruz Institute
}

\author{
Roberto Magalhães Pinto 1, 2, 3, Delir Corrêa Gomes 1, 2, Rodrigo Caldas Menezes 1, \\ Cláudia Torres Gomes ${ }^{1} \&$ Dely Noronha ${ }^{1}$
}

' Laboratório de Helmintos Parasitos de Vertebrados, Departamento de Helmintologia, Instituto Oswaldo Cruz. Avenida Brasil 4365, 21045-900 Rio de Janeiro, Rio de Janeiro, Brasil.

${ }^{2} \mathrm{CNPq}$ research fellow.

${ }^{3}$ Corresponding author. E-mail: rmpinto@ioc.fiocruz.br

\begin{abstract}
Helminth samples $(\mathrm{n}=35)$ recovered from Oryctolagus cuniculus (Linnaeus, 1758) Lilljeborg, $1873(3)$ and from another rabbit species, Sylvilagus brasiliensis (Linnaeus, 1758) Thomas, 1901 (32), from August 1909 to February 1948 and that are deposited in the Helminthological Collection of the Oswaldo Cruz Institute were analyzed. The studied samples were represented by the cysticercus of the cestode Taenia pisiformis (Bloch, 1780) and by the nematodes Passalurus ambiguus (Rudolphi,1819), Vianella fariasi (Travassos, 1915), Longistriata perfida Travassos, 1943, Trichostrongylus retortaeformis (Zeder, 1800). The scope of the present investigation is to survey the parasites infecting these hosts, commonly used as laboratory animal models in scientific research and supply figurative data on the helminths in order to provide their easy identification, since the presence of autochthonous parasite burdens, if undetected or misinterpreted, can alter the final results of experimental assays, mainly those related to immunological approaches, when cross-reactions can occur.

KEY WORDS. Cestodes, nematodes, Oryctolagus cuniculus, prevalences, Sylvilagus brasiliensis.
\end{abstract}

RESUMO. Trinta e cinco amostras de helmintos coletadas de Oryctolagus cuniculus (Linnaeus, 1758) Lilljeborg, 1873 (3) e de uma outra espécie de coelho, Sylvilagus brasiliensis (Linnaeus, 1758) Thomas, 1901 (32), de agosto de 1909 a fevereiro de 1948 e que estão depositadas na Coleção Helmintológica do Instituto Oswaldo Cruz, foram analisadas. As amostras estudadas estão representadas pelo cisticerco do cestóide Taenia pisiformis (Bloch, 1780) e pelos nematóides Passalurus ambiguus (Rudolphi, 1819), Vianella fariasi (Travassos, 1915), Longistriata perfida Travassos, 1943, Trichostrongylus retortaeformis (Zeder, 1800). O objetivo da presente investigação é o de inventariar os parasitos que infectam estes hospedeiros, comumente utilizados como modelos de animais de laboratório na pesquisa científica e fornecer dados figurativos sobre os helmintos a fim de facilitar sua identificação, uma vez que, cargas parasitárias autóctones, caso não detectadas ou erroneamente avaliadas, podem alterar o resultado final de protocolos experimentais, principalmente dos relacionados a ensaios imunológicos, quando infecções cruzadas podem ocorrer.

PALAVRAS CHAVE. Cestóides, nematóides, Oryctolagus cuniculus, prevalences, Sylvilagus brasiliensis.

Rabbits are one of the most common laboratory animals, used worldwide in experiments to evaluate different biological parameters. Considering that the rabbit is a high-responder model for immunological assays and in Brazil, as in other countries, this animal is either conventionally maintained in animal facilities to be used in scientific research or is also available in pet shops and in backyard colonies for commercial purposes.

The helminth fauna of laboratory mice, rats, hamsters, guinea pigs and gerbils has been evaluated in Brazil and compared to that recovered from some of these animal models, openly kept in pet stores; the importance of the adequate identification of the parasites infecting these hosts has been strongly emphasized (Bazzano et al. 2002, Gonçalves et al. 1998, Pinto et al. 1994, 2001a, b, 2002, 2003 a, b).

The present survey is related to helminths recovered from two rabbit species in Brazil; the parasites were identified and figured.

Revista Brasileira de Zoologia 21 (3): 599-604, setembro 2004 

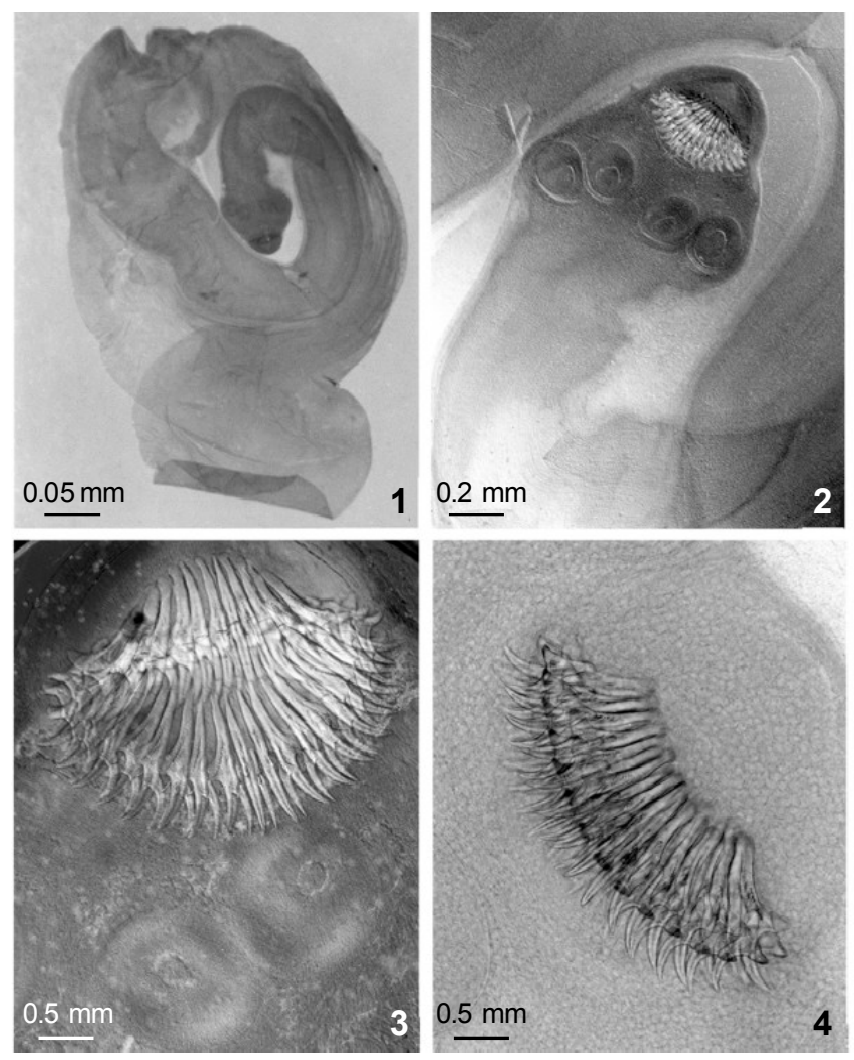
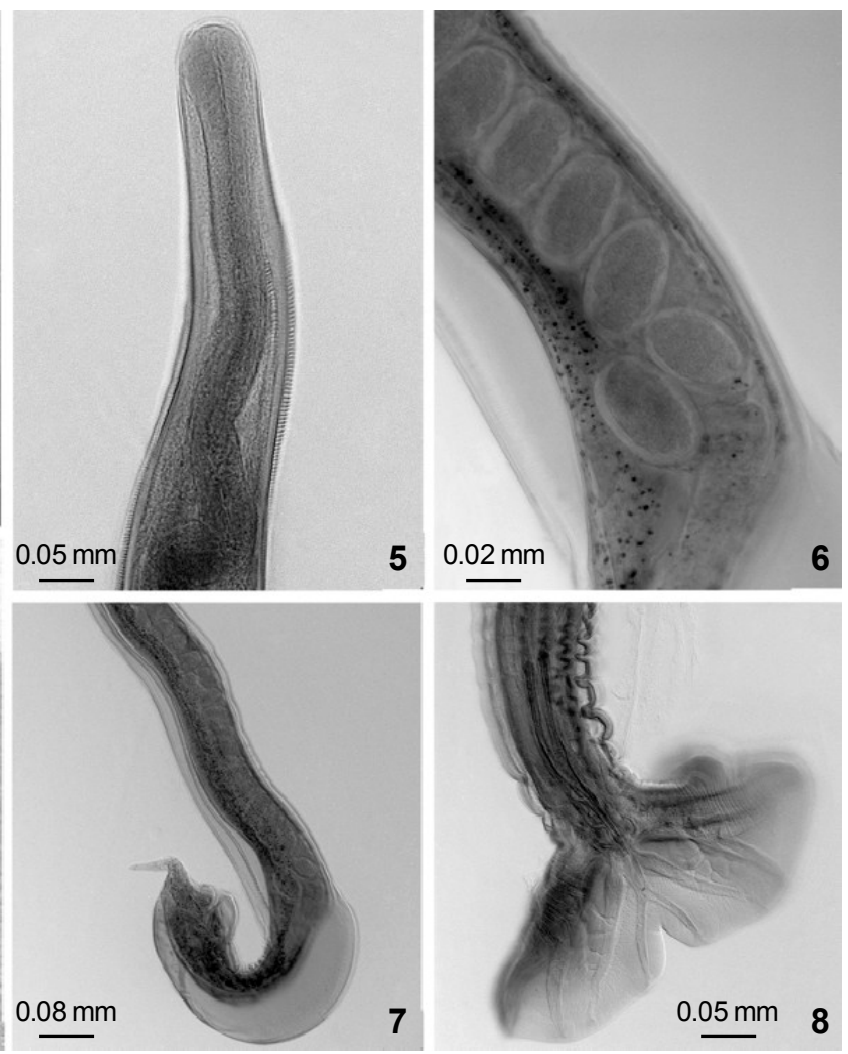

Figures 1-8. (1-4) Cysticercus of Taenia pisiformis: (1) total; (2) scolex, showing rostelar hooks and the four suckers; (3) detail of rostelar hooks and suckers; (4) detail of rostelar hooks of another specimen. (5-8) Vianella fariasi: (5) anterior portion of female, ventral view; (6) eggs in utero; (7) posterior portion of female, lateral view; (8) posterior portion of male, ventral view.

\section{MATERIAL AND METHODS}

The presently investigated 35 helminth samples (32 from Sylvilagus brasiliensis (Linnaeus, 1758) Thomas, 1901 (= Lepus brasiliensis = Sylvilagus minensis) and three from Oryctolagus cuniculus (Linnaeus, 1758) Lilljeborg, 1873 (= Lepus cuniculus), captured in the States of Rio de Janeiro (RJ), Espírito Santo (ES), Mato Grosso do Sul (MS), respectively, and that were previously deposited in the Helminthological Collection of the Oswaldo Cruz Institute (CHIOC) as wet material, were routinely processed for study as described elsewhere (PINTo et al. 1994) and those already preserved as whole mounts were also examined. Referred numbers of deposit do not always represent the amount of samples, since some sequential whole mounts can derive from a same sample kept as wet material, receiving another file number. Classification follows VICENTE et al. (1997) for the nematodes and Rausch (1994) for the cestodes and systematic of hosts is in accordance with HoffmAnN (1993). The ecological concept (prevalence) is used according to Bush et al. (1997). Photomicrographs were obtained in a Zeiss
Axiophot brightifield microscope in a Differential Interference Contrast (DIC) system with a 100 ISO Kodak film.

\section{RESULTS}

Results so far obtained showed that the samples recovered from Sylvilagus brasiliensis were represented by the cysticercus of one cestode and three nematode species.

\section{Taenia pisiformis (Bloch, 1780) (= Cysticercus pisiformis) (Figs 1-4)}

Taxonomic summary: Taeniidae; site of infection: peritonium; locality: Rio de Janeiro, RJ; specimens deposited: CHIOC no. 4402, 4403 (whole mounts), 20042 (wet material).

\section{Vianella fariasi (Travassos, 1915) Travassos, 1918 (Figs 5-8)}

Taxonomic summary: Trichostrongyloidea, Viannaidae, Viannainae; site of infection: small intestine; localities: Angra dos Reis, RJ, Rio de Janeiro, RJ, Linhares, ES; specimens deposited: CHIOC no. 668 a-c, (whole mounts), 1789, 4283, 5087, 8042, 9238 (wet material), 9302 a-b (whole mounts), 9328, 12243, 12342, 14730, 17673 - 17676, 17678, 7685, 20041, 20043, 20044 (wet material). 

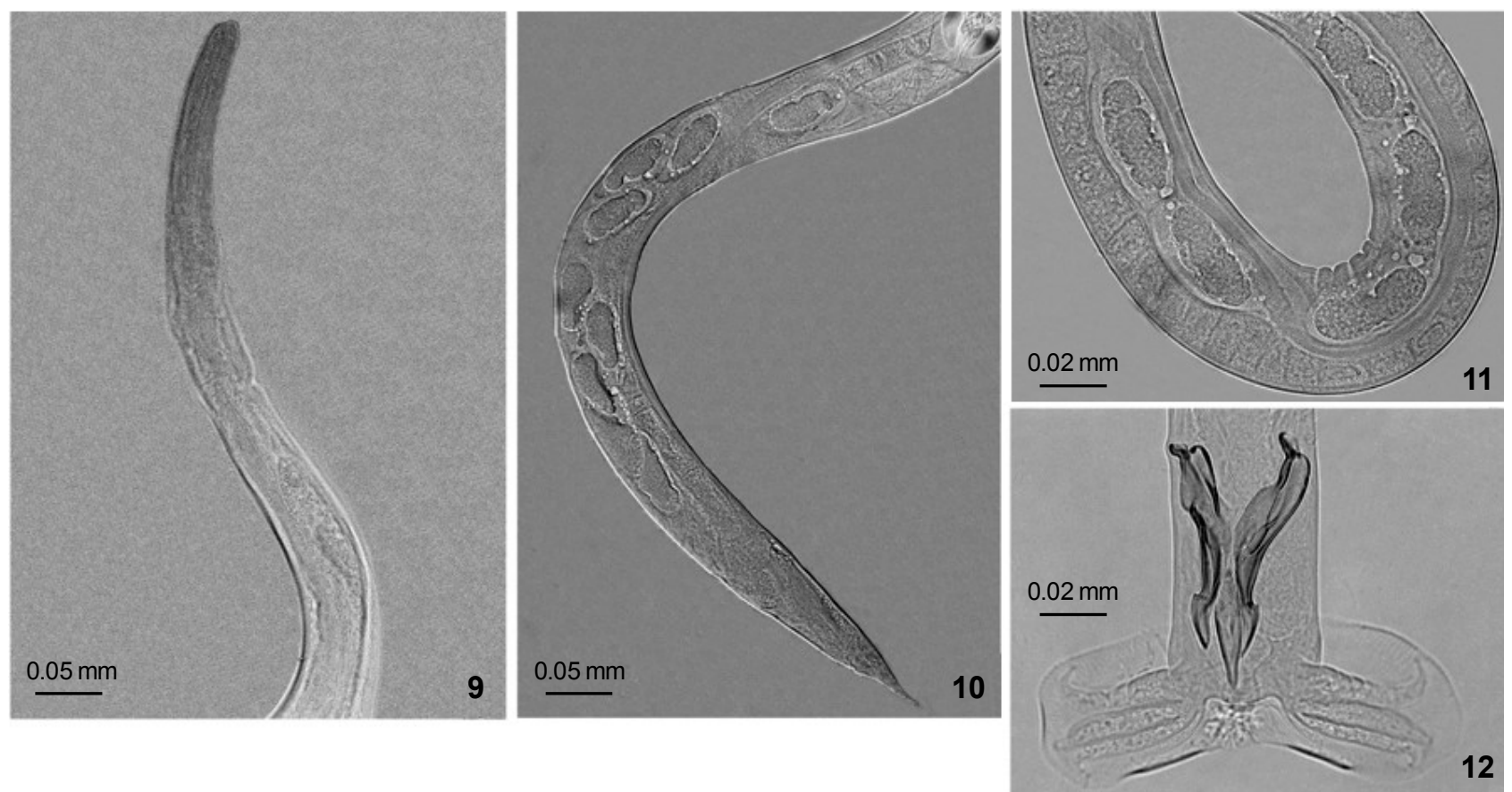

Figures 9-12. Trichostrongylus retortaeformis: (9) anterior portion of female, ventral view; (10) posterior portion of female, lateral view; (11) eggs in utero; (12) posterior portion of male, ventral view.

\section{Trichostrongylus retortaeformis (Zeder, 1800) Looss, 1905 (Figs 9-12)}

Taxonomic summary: Trichostrongyloidea, Trichostrongylidae, Trichostrongylinae; site of infection: small intestine; locality: Rio de Janeiro, RJ; specimens deposited: CHIOC no. 15430 a-c (whole mounts).

\section{Longistriata perfida Travassos, 1943 (Figs 13-16)}

Taxonomic summary: Trichostrongyloidea, Trichostrongylidae, Heligmosominae; site of infection: small intestine; locality: Salobra, MT; specimens deposited: CHIOC no.14387 (wet material); 14395-14401 a-b (whole mounts).

The cestode $T$. pisiformis represented $9.09 \%$ of the samples. The most prevalent nematode species in specimens of $S$. brasiliensis was $V$. fariasi, occurring in $60.6 \%$ of the samples, followed by L. perfida in $24.2 \%, P$. ambiguus and $T$. retortaeformis in $3.03 \%$, each.

The worms recovered from specimens of Oryctolagus $\mathrm{cu}$ niculus were represented only by nematodes in the three available samples examined.

\section{Passalurus ambiguus (Rudolphi, 1819) Dujardin, 1845 (Figs 17-21)}

Taxonomic summary: Oxyuroidea, Oxyuridae; site of infection: large intestine; locality: Rio de Janeiro, RJ; specimens deposited: CHIOC no. 7520, 7615 (wet material).

\section{Trichostrongylus retortaeformis (Zeder, 1800) Looss, 1905}

Taxonomic summary: Trichostrongyloidea, Trichostron- gylidae, Trichostrongylinae; site of infection: large intestine; locality: Rio de Janeiro, RJ; specimen deposited: CHIOC no. 15326 (whole mount).

\section{DISCUSSION}

In Brazil few are the accounts related to taxonomic and systematic studies of the helminths naturally infecting rabbits and most of the available data refer to check lists of the metazoan endoparasites with no further reports on prevalence and size of the worm burdens. Previous data refer to the parasitism of Brazilian rabbits with the nematodes Gongylonema neoplasticum (Fibiger \& Ditlevsen, 1914), Paraspidodera uncinata (Rudolphi, 1819) Travassos, 1914, Passalurus ambiguus, Strongyloides papillosus (Wedler, 1856) (= Strongylus papillosus), Trichostrongylus retortaeformis in Oryctolagus cuniculus; Vianella fariasi (= Viannaia fariai) and Longistriata perfida are referred in Sylvilagus brasiliensis (VICENTE et al. 1997) and the cestodes Taenia multiceps (Gervais, 1847) (= Multiceps multiceps), T. serialis (Leske, 1780) (= Multiceps serialis = Coenurus serialis $),$ Taenia pisiformis in O. cuniculus and Taenia macrocystis (Diesing, 1850) (= Hydatigena macrocystis) in S. brasiliensis (Travassos 1965, Costa $\&$ Freitas 1970).

Although the helminths of rabbits, mainly those harbored by specimens of $O$. cuniculus, distributed worldwide, have been largely investigated, data so far obtained from Brazilian rabbits report to the finding of a quite different nematode fauna 

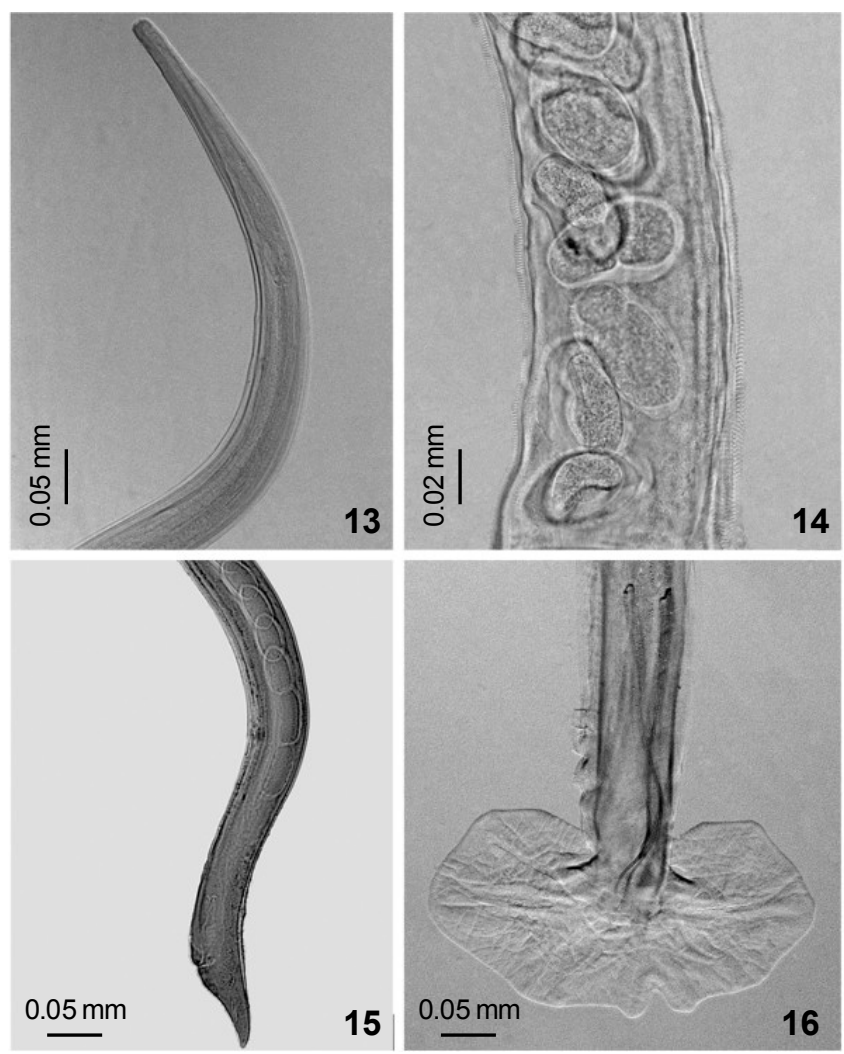
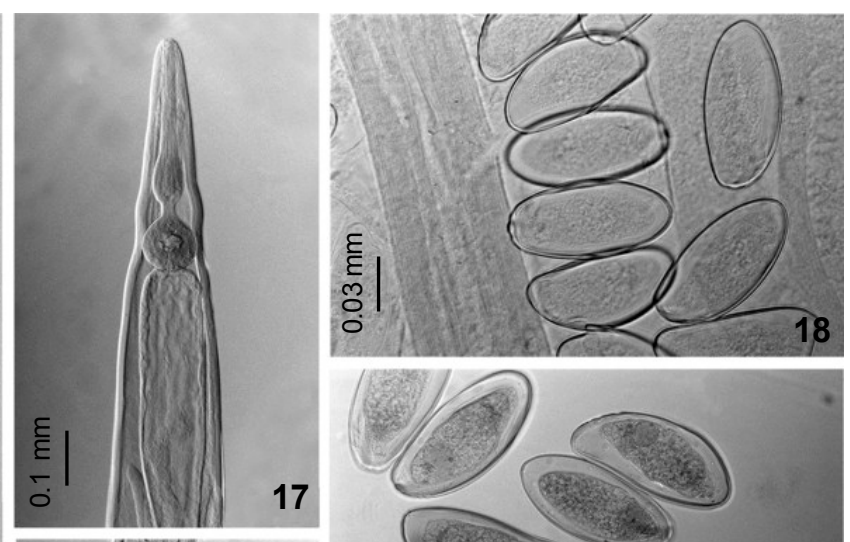

17
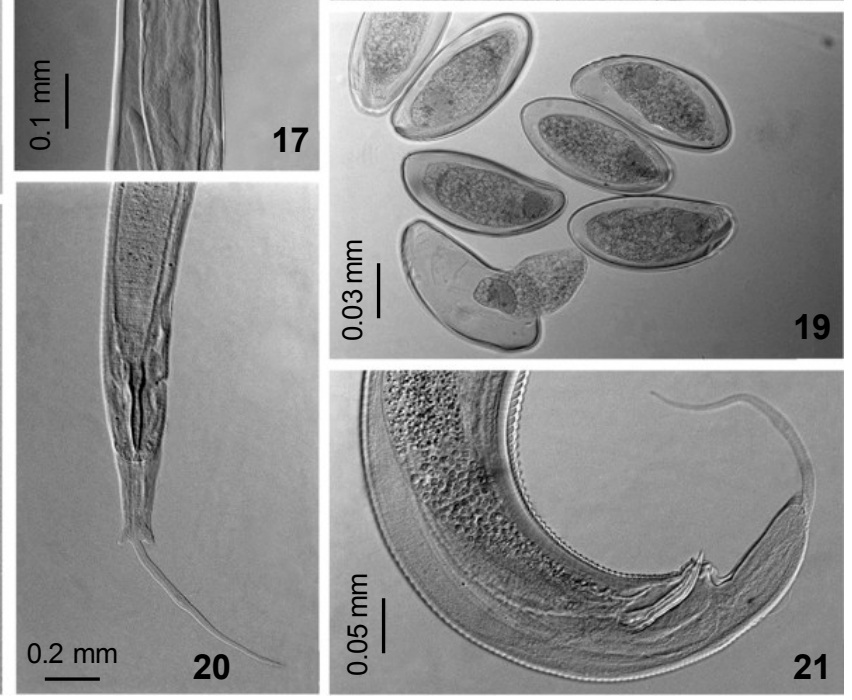

Figures 13-21. (13-16) Longistriata perfida: (13) anterior portion of male, ventral view; (14) eggs in utero; (15) posterior portion of female, lateral view; (16) posterior portion of male, ventral view. (17-21) Passalurus ambiguus: (17) anterior portion of male, ventral view; (18) eggs in utero; (19) mature deposited eggs; (20) posterior portion of male, ventral view; (21) posterior portion of male, lateral view.

when compared to that recovered from hosts of this species in other localities, suggesting that some of the parasites may be endemic.

Among the nematodes parasitizing rabbits in Brazil, only T. retortaeformis, $P$. ambiguus and $S$. papillosus have been referred infecting specimens of $O$. cuniculus from other countries mainly in Australia, England, Scotland and Spain; conversely, other nematode and cestode species were reported from this host overseas (Nwaorgu \& ConNan 1980, Boag 1985, 1987, BoAg \& IAson 1986, Boag \& Kolb 1989, BoAg \& Garson 1993, Allan et al. 1999, Molina et al. 1999, Новвs et al. 1999).

In the case of the helminths recovered from S. brasiliensis that is distributed from Mexico southward through Central and South America, as far as Peru, Bolivia, Argentina and Brazil, the available data on the parasites are on the basis of Brazilian samples only, except for the cestode T. macrocystis, also reported from other countries (SChMidt \& MarTin 1978, TiekotTer 1981, MaRChIONDO et al. 1986).

Similarly to what happens with $T$. macrocystis from $S$. brasiliensis, there are no morphometric and figurative data available in Brazil for the other cestode species $T$. serialis, $T$. hydatigena, T. pisiformis and T. multiceps that can infect specimens of $O$. cuniculus in our country as well as other vertebrate hosts worldwide; nevertheless, morphological data related to these species have been reported elsewhere (VArela 1971, Beveridge \& Rickard 1976, Edwards \& Herbert 1981, Kietzmann \& Hugghins 1986, Soerensen et al. 1974).

Paraspidodera uncinata, a common nematode species that infects guinea pigs in Brazil and overseas and another nematode Gongylonema neoplasticum frequently referred in rodents worldwide, and of unusual occurrence in rabbits, although listed as parasites infecting specimens of O. cuniculus in Brazil by VICENTE et al. (1997) were not found among the presently studied samples; nevertheless, complete morphometric data on these species were reported by Pinto et al. (2002) and Kasegawa et al. (1994), respectively.

Females of Passalurus ambiguus, presently studied showed, as expected, typical oxyurid eggs without any shell ornamentation, in disagreement with was illustrated by PINTO (1945) and Vicente et al. (1997). The lack of ornamentations was also confirmed by Rodriguez et al. (1973) and thus, suggesting the occurrence of an artifact, misinterpreted by the former authors. 
As already stated (PINTO et al. 1994, 2001b, 2002), the proper identification of parasites harbored by animal models used in scientific experiments is of great importance, considering that they, if overlooked or misinterpreted, can alter final results, mainly those related to immunological assays, when cross-reactions can occur.

Figurative data on the species presently examined are supplied, taking into account that most of the species have been poorly illustrated since their original description.

\section{ACKNOWLEDGMENTS}

To Heloísa Maria Nogueira Diniz, Laboratório de Imagens, Diretoria do Instituto Oswaldo Cruz, Fiocruz, for technical photographic support.

\section{REFERENCES}

Allan, J.C.; P.S. Craig; J. Sherington; M.T. Rogan; D.M. Storey; S. Heath \& K. Iball 1999. Helminth parasites of the wild rabbit Oryctolagus cuniculus near Mmalham Tarn, Yorkshire, UK. Journal of Helminthology, Wallingford, 73: 289-294.

Bazzano, T.; T.I. Restel; R.M. Pinto \& D.C. Gomes. 2002. Patterns of infection with the nematodes Syphacia obvelata and Aspiculuris tetraptera in conventionally maintained laboratory mice. Memórias do Instituto Oswaldo Cruz, Rio de Janeiro, 97: 847-853.

Beveridge, I. \& M.D. Rickard. 1976. The development of rostelar hooks of Taenia pisiformis. International Journal for Parasitology, Oxford, 6: 55-59.

BOAG, B. 1985. The incidence of helminth parasites from the wild rabbit Oryctolagus cuniculus (L.) in eastern Scotland. Journal of Helminthology, Wallingford, 59: 61-69.

. 1987. The helminth parasites of the wild rabbit Oryctolagus cuniculus and the brown hare Lepus capensis from the Isle of Coll, Scotland. Journal of Zoology, London, 212: 352-355.

BOAG, B. \& G. IAsON. 1986. The occurrence and abundance of helminth parasites of the mountain hare Lepus timidus (L.) in Aberdeenshire, Scotland. Journal of Helminthology, Wallingford, 60: 92-98.

BoAG, B. \& H. Kolb. 1989. Influence of host age and sex on nematode populations in the wild rabbit (Oryctolagus cuniculus L.). Proceedings of the Helminthological Society of Washington 56: 116-119.

BOAG, B. \& P.J. Garson. 1993. Helminth infections of weaning rabbits from Holy Island, Northuberland. Journal of Zoology, London, 230: 323-326.

Bush, A.O.; K.D. Lafferty; J.M. Lotz \& A.W. Shostak. 1997. Parasitology meets ecology on its own terms: Margolis et al. revisited. Journal of Parasitology, Lawrence, 83: 575-583.

Costa, H.M.A. \& M.G. Freitas. 1970. Lista de helmintos parasitos dos animais domésticos do Brasil. Arquivos da Escola de Veterinária, Belo Horizonte, 22: 33-94.
EDWARDS, G.T. \& I.V. HerberT. 1981. Some quantitative characters used in the identification of Taenia hydatigena, T. ovis, T. pisiformis, and T. multiceps metacestodes. Journal of Helminthology, Wallingford, 55: 1-7.

Gonçalves, L; R.M. Pinto; J.J. Vicente; D. Noronha \& D.C. GoMES. 1998. Helminth parasites of conventionally maintained laboratory mice - II. Inbred strains with an adaptation of the anal swab technique. Memórias do Instituto Oswaldo Cruz, Rio de Janeiro, 93: 121-126.

Hoвbs, R.P.; L.E. Twigg; A.D. Elliot \& A.G. Wheeler. 1999. Evaluation of the association of parasitism with mortality of wild rabbits Oryctolagus cuniculus (L.) in southeastern Australia. Journal of Parasitology, Lawrence, 85: 803-808.

Hoffman, R.S. 1993. Order Lagomorpha, p. 806-827. In: D.E. Wilson \& D.A.M. ReEder (Eds). Mammal Species of the World. Washington, Smithsonian Institution Press, XVII+ 1206p.

Kasegawa, H.; J. Kobayashi \& M. Otsuru. 1994. Helminth parasites collected from Rattus rattus on Lanyu, Taiwan. Journal of the Helminthological Society of Washington 61: 95-102.

Kietzmann, G.E. \& E.J. Hugghins. 1986. Helminths of lagomorphs in South Dakota. Journal of Wildlife Diseases, Washington, 22: 276-278.

Lepitzki, D.A.W.; A. Woolf \& B.M. Bunn. 1992. Parasites of cottontail rabbits of southern Illinois. Journal of Parasitology, Lawrence, 78: 1080-1083.

Marchiondo, A.A; F. KarPowitz \& G.A. Konder. 1986. Parasites of the bobcat (Lynx rufus pallescens) in central and southern Utah. Proceedings of the Helminthological Society of Washington 53: 113-116.

Molina, X.; J.C. Casanova \& C. Feliu. 1999. Influence of host weight, sex and reproductive status on helminth parasites of the wild rabbit, Oryctolagus cuniculus, in Navarra, Spain. Journal of Helminthology, Wallingford, 73: 221-225.

Nwaorgu, O.C. \& R.M. Connan. 1980. The importance of arrested larvae in the maintenance of patent infections of Strongyloides papillosus in rabbits and sheep. Veterinary Parasitology, Cambridge, 7: 339-346.

Pinto, C. 1945. Helmintologia, p. 219-454. In: C. Pinto (Ed.). Zooparasitos de interesse médico e veterinário. Rio de Janeiro, Editora Scientífica, 541p.

Pinto, R.M.; J.J. Vicente; D. Noronha; L. Gonçalves \& D.C. GoMES. 1994. Helminth parasites of conventionally maintained laboratory mice. Memórias do Instituto Oswaldo Cruz, Rio de Janeiro, 89: 33-40.

Pinto, R.M.; L. Gonçalves; D. Noronha \& D.C. Gomes. 2001a. Worm burdens in outbred and inbred laboratory rats with morphometric data on Syphacia muris (Yamaguti, 1935) Yamaguti, 1941 (Nematoda, Oxyuroidea). Memórias do Instituto Oswaldo Cruz, Rio de Janeiro, 96: 133-136.

Pinto, R.M.; L. Gonçalves; D.C. Gomes \& D. Noronha. 2001 b. Helminth fauna of the golden hamster Mesocricetus auratus in Brazil. Contemporary Topics in Laboratory Animal 
Science, Memphis, 40: 21-26.

Pinto, R.M.; D.C. Gomes; L.C. Muniz-Pereira \& D. Noronha. 2002. Helminths of the guinea pig, Cavia porcellus (Linnaeus) in Brazil. Revista Brasileira de Zoologia, Curitiba, 19 (Supl. 1): 261-269.

Pinto, R.M.; D.C. Gomes; R.C. Menezes; L.C. Muniz-Pereira \& D. Noronha. 2003a. First natural helminth infection in the Mongolian gerbil Meriones unguiculatus (Rodentia, Muridae), parasitized with Dentostomella translucida (Nematoda, Heteroxynematidae) in the Neotropical region. Brazilian Journal of Biology, São Carlos, 63: 173-175.

PInTo, R.M.; D.C. Gomes; D. Noronha. 2003b. Evaluation of coinfection with pinworms (Aspiculuris tetraptera, Dentostomella translucida, and Syphacia obvelata) in gerbils and mice. Contemporary Topics in Laboratory Animal Science, Memphis, 42: 46-48.

RausCh, R.L. 1994. Family Taeniidae Ludwig, 1886, p. 665-677. In: L.F. KhaliL; A. Jones \& R.A. BRAY (Eds). Keys to the Cestode Parasites of Vertebrates. CAB International, Oxon, XIII + $751 \mathrm{p}$.

Rodriguez, J.R.; D.G. Pozo \& J.L. Herrera. 1973. Estudios sobre el genero Passalurus, Dujardin, 1845, parasitando al Orycto- lagus cuniculus domestica (L.) y Lepus granatensis (R.). Revista Iberica de Parasitologia, Granada, 33: 315-329.

SchmidT, G.D. \& R.L. Martin. 1978. Tapeworms of the Chaco Boreal, Paraguay, with two new species. Journal of Helminthology, Wallingford, 52: 205-209.

Soerensen, B.; L.Z. Neto; M.D. Perez; G.M. Bulka \& A.E.G. Ono. 1974. Presença de Cysticercus pisiformis (Bloch, 1780) em coelho e lebre importados. Memórias do Instituto Butantan, São Paulo, 38: 63-68.

TieкоттеR, K.L. 1981. A rapid technique for the identification of taenioid cestodes using unstained scolices. Transactions of the Nebraska Academy of Sciences, Lincoln, 9: 55-56.

TRAVASSOS, L. 1965. Contribuição para o inventário crítico da Zoologia no Brasil. Fauna helmintológica: considerações preliminares - cestódeos. Rio de Janeiro, Universidade Federal do Rio de Janeiro, 84p.

Varela, M.C. 1971. Nouvelle contribution a l'etude des helminthocenoses des lievres au Portugal. Anais da Escola Superior de Medicina Veterinária, Lisboa, 13: 165-171.

Vicente, J.J.; H.O. Rodrigues; D.C. Gomes \& R.M. Pinto. 1997. Nematóides do Brasil. Parte V: Nematóides de mamíferos. Revista Brasileira de Zoologia, Curitiba, 14 (Supl. 1): 1-452.

Received in 02.II.2004; accepted in 28.VII.2004.

Revista Brasileira de Zoologia 21 (3): 599-604, setembro 2004 